\title{
Bodies and Intimate Relations in Organizations and Work
}

\author{
Mik-Meyer, Nanna; Roelsgaard Obling, Anne; Wolkowitz, Carol
}

Document Version

Accepted author manuscript

Published in:

Gender, Work and Organization

DOI:

10.1111/gwao.12197

Publication date:

2018

License

Unspecified

Citation for published version (APA):

Mik-Meyer, N., Roelsgaard Obling, A., \& Wolkowitz, C. (2018). Bodies and Intimate Relations in Organizations and Work. Gender, Work and Organization, 25(1), 1-8. https://doi.org/10.1111/gwao.12197

Link to publication in CBS Research Portal

\section{General rights}

Copyright and moral rights for the publications made accessible in the public portal are retained by the authors and/or other copyright owners and it is a condition of accessing publications that users recognise and abide by the legal requirements associated with these rights.

Take down policy

If you believe that this document breaches copyright please contact us (research.lib@cbs.dk) providing details, and we will remove access to the work immediately and investigate your claim. 


\section{Bodies and Intimate Relations in Organizations and Work}

\section{Nanna Mik-Meyer, Anne Roelsgaard Obling, and Carol Wolkowitz}

Journal article (Accepted manuscript*)

\section{Please cite this article as:}

Mik-Meyer, N., Roelsgaard Obling, A., \& Wolkowitz, C. (2018). Bodies and Intimate Relations in Organizations and Work. Gender, Work and Organization, 25(1), 1-8. https://doi.org/10.11l1/gwao.12197

This is the peer reviewed version of the article, which has been published in final form at DOI: https://doi.org/10.1111/gwao.12197

This article may be used for non-commercial purposes in accordance with Wiley Terms and Conditions for Self-Archiving

* This version of the article has been accepted for publication and undergone full peer review but has not been through the copyediting, typesetting, pagination and proofreading process, which may lead to differences between this version and the publisher's final version AKA Version of Record. 
Final version before publishing. Full reference: Mik-Meyer, N., Obling, A.R. \& Wolkowitz, C. (2018)

Bodies and intimate relations in organizations and work, Gender, Work \& Organization, 25(1): 1-8.

BODIES AND INTIMATE RELATIONS IN ORGANIZATIONS AND WORK

\author{
Nanna Mik-Meyer ${ }^{1}$ \\ Copenhagen Business School, Denmark \\ Anne Roelsgaard Obling \\ Copenhagen Business School, Denmark
}

Carol Wolkowitz

University of Warwick, United Kingdom

1 Please direct correspondence to Nanna Mik-Meyer, Department of Organization, Copenhagen Business School, Kilevej 14A, 4th floor, 2000-Frederiksberg C, Denmark; email: nmm.ioa@cbs.dk. 


\section{BODIES AND INTIMATE RELATIONS IN ORGANIZATIONS AND WORK}

Since social scientists began publishing in the area of 'Bodies and Intimate Relations in Organizations and Work', which is the title of this Special Issue, there has been a significant increase in interest in this area. Feminist scholarship has made a particularly strong contribution to the study of bodies and intimacy at work, but research is not confined to studies of gender at work, or even to types of, or aspects of, work in which bodies have an obviously prominent place, such as health care or aesthetic and aestheticized labour (for recent studies, see McDowell, 2009; Purcell et al., 2017; Shaw, 2014; Van den Brock, 2017; Williams and Connell, 2010). Over nearly 20 years, bodies at work has become an attractive focus of organization studies (e.g. Jeanes et al., 2011; Hassard et al., 2000; Cooper, 2009; Coupland, 2015; Mik-Meyer, 2015, 2016a) and management studies (Courpasson and Monties, 2016; Johansson et al., 2017), with studies drawing on diverse frameworks, such as actor-network theory (Mol, 2002), affect theory (Fotaki et al., 2017; Seigworth and Gregg, 2010) and sensemaking theory (Küpers, 2009). It is apparent that 'the body' in social theory and research can no longer be characterized as 'an absent presence', to paraphrase Shilling (2003/1993, p. 19). This Special Issue contributes to the development of scholarship on bodies in work and organization, and it presents six fascinating papers in this field. As in the wider literature on bodies and intimate relations in organizations and work, the authors in this Special Issue attend to issues of commonality as well as difference, especially those (re)constructed within the workplace.

Though the authors of this Special Issue refer to general constructions of gendered bodies in organizations, they also analyse concrete experiences of embodiment. It is the workplace relationships within specific assemblages of actions and practices that take centre stage. The authors demonstrate that even in what might seem geographically or emotionally distant kinds of work, bodies matter. Hence, the authors draw on a surprising range of theory, from phenomenology to 
labour process theory. They present research from Canada, India, Australia, Denmark and the UK, and they include both original qualitative empirical research as well as reinterpretations of wider literature.

Before moving on to look in more depth at the issues raised by the Special Issue, we shortly signal the articles' main foci. Two of the articles are very explicit not only in recognizing the transnational character of research on bodies in organizations and work but also in identifying the contemporary workplace as a transnational site. Embodied relations and identities are embedded in wider power dynamics. For instance, Sweta Rajan-Rankin's Invisible Bodies and Disembodied Voices? Embodiment and Transnational Service Work focuses on identity construction in Indian call centres. The call centres serve US customers half a world away, so the incentives and constraints shaping embodied identity construction and resistance reflect wider historical processes and contemporary forms of globalization. Another example of how the global is intertwined with the local is the article by Elaine Swan and Rick Flowers, Lasting Impressions: Ethnic Food Tour Guides and Body Work in Southwestern Sydney. The authors analyse ethnic neighbourhood tourism in emerging sustainable and 'authentic' tourism markets (see also Sims, 2009). Swan and Flowers examine the experiences of women that work as food tour guides on food tours in enclaves of recent migrants in Sydney, Australia. Although both the tour participants and the ethnic food vendors live locally, the tour guides must use their own bodies to manage often tense interactions between groups with different backgrounds. The participants of the food tours often display bodily expressions of disgust when introduced to ethnic foods.

The focus in this last article on a surprisingly intimate form of embodied relation is further developed in three other papers in which the social relations of touch are addressed. Rachel Lara Cohen and Carol Wolkowitz's The Feminization of Body Work seeks to explain the prevalence of low pay in body work occupations in terms of both cultural and economic constraints. The 
authors examine how the gender composition of the care work and hairdressing labour forces in the UK is embedded in wider cultural expectations regarding touch: women's touch is associated with caring, whereas male touch may be perceived as aggressive or as derived from expertise. In the article by Agnete Meldgaard Hansen and Annette Kamp, gendered ways of constructing worker identities is explored further, this time in an occupation undergoing change. Their article From Carers to Trainers: Professional Identity and Body Work in Rehabilitative Elder Care shows how Danish care work is being transformed. These researchers argue that current attempts to raise the status of care work and employ more men go hand in hand with attempts to reduce the amount of physical touch required from the carers. Care work with the elderly now involves training the elderly to look after themselves, and thereby reducing the amount of touch required. Workers' new roles as trainers have implications for how workers understand their own bodies. The focus on intimacy is also discussed in Robyn Lee's Breastfeeding Bodies: Intimacies at Work. Her review of the literature on breastfeeding and work suggests that breastfeeding can only be recognized as labour if we rethink the binary relationship between productive and reproductive work. The lessons for recognizing other kinds of relational work as labour, including work in the so-called private sphere, are manifold. However, as these examples show, raising the issue of embodiment is often a gendered action.

Finally, the Special Issue includes the article Stress at Work: Gendered Dysappearance and the Broken Body at Work by Sarah Yates, Kathleen Riach and Marjana Johansson. They examine senior British women police officers' accounts of stress, arguing that the 'causes' that often are assumed to trigger police officer stress, such as potentially violent and unpredictable interactions with members of the public, are less important than the institutionally embedded norms of masculinity within police organizations. This focus on gendered interactional dynamics is picked 
up to some extent in all the Special Issue papers, and can be linked to wider attempts to incorporate bodily interaction as a major facet of work experience and organizational life.

\section{WHAT'S IN A NAME?}

Rather confusingly, social scientists still have no agreed-on term for the field of study that this Special Issue addresses. The reason is that 'the body' is contentious, in that it implies the existence of a universal foundation for very different embodied social identities and coping strategies. Some may feel (and we agree) that it is better to talk about 'bodies' in the plural such that, for instance, the diversity of the constructions and experiences which the authors of the articles in this Special Issue identify are more readily foregrounded. The term 'embodiment' is especially useful because it highlights the processual aspects of becoming embodied individuals, rather than assuming there to be an original essence.

Mascia-Lees (2011) reflects on the issue of defining the field of study in her introduction to a compendium of articles on 'the anthropology of the body and embodiment'. She argues that anthropologists have become increasingly wary of the term 'the body' because it can universalize and normalize particular understandings of embodiment (2011, p. 3). While continuing to use the phrase 'the body' - always in quotation marks - Mascia-Lees and the other contributors suggest that no single phrase can replace it. They opt for either 'specified bodies' (e.g. the virtual body, the moving body, bodies-in-practice) or the simple plural, 'bodies'. Shilling's (2003/1993) use of the phrase 'body studies' to replace the 'sociology of the body' can also be understood as a way to avoid the reification implied by the latter.

'Body work' is another central concept deployed by many of the authors in this Special Issue. Developed initially by Kang (2003, 2010), Twigg (2000, 2006) and Wolkowitz (2002, 2006), there is still no agreement over how the term should be defined, even ten years after 
Gimlin (2007) summarised four distinct usages of the term. In this Special Issue, Cohen and Wolkowitz define 'body work' in terms of jobs requiring workers or practitioners to physically (and usually extensively) touch clients' or customers' bodies, which they argue affects the nature of the interactions. This is an example of a narrow but robust definition which allows them to identify what they call 'body work occupations' and to enumerate the size of the body work labour force. Hansen and Kamp's study of domiciliary care work uses body work in a similar sense but expands the definition to include the ways in which the kind of body work workers perform on others also frames their body work on themselves, so the two are mutually constitutive. Other authors within the Special Issue expands the meaning of 'body work' even further. For instance, Swan and Flowers follow McDowell (2009) in using the term 'body work' to explore how workers manage both their own and others' bodies in face-to-face, service-sector interactions, whether or not touch is involved. Rajan-Rankin identifies the body work undertaken by call centre workers in relation to clients, even though the workers and clients can only imagine each other's bodies. In this latter case, 'body work' has to do with the way in which workers apprehend and perform appropriate emotions, another of Gilman's (2007) possible definitions. A final approach is taken by Yates, Riach and Johansson. They talk about what Gimlin termed 'body-making', that is, exploring 'the production of bodies through the work they do' (2007, p. 363). This includes not just obvious changes, such as the development of muscles when doing manual work, but changes in accent, dress and deportment. It will be interesting to see how far this expansive use of the concept 'body work' will be developed in further research, and if this breadth enriches scholarly research or impedes greater precision.

A second conceptual issue that connects most of the articles has to do with the different ways the authors think about the interactions between bodies and their relative openness to the world and to each other (Mik-Meyer, 2016a, 2016b). This interest in interaction is strongest in the article by Swan and Flowers, who draw on Ahmed and Stacey's (2001) problematization of skin 
as a natural boundary or container for human bodies. Swan and Flowers seek to understand the 'impression', to use Ahmed and Stacey's term, that bodies make on each other through 'the physical and affective encounters between subjects and the histories on which these encounters draw' (Grabham, 2008, p. 198). Similarly, Rajan-Rankin is also interested in the impressions Indian call centre workers and American clients make on each other. In contrast, Lee uses Diprose's (2002) concept of 'corporeal generosity' to highlight a mother's openness to her baby's needs, and contrasts that with bounded selves who are involved in exchange relations. The workers examined by Cohen and Wolkowitz, and Hansen and Kamp, are in an ambivalent situation, struggling to maintain their identities as bounded selves while engaged in body work with stigmatized 'leaky bodies'. Finally, Yates, Riach and Johansson are interested in how recognizing one's stress also brings one's body to consciousness; otherwise, according to Leder (1990), it disappears from consciousness.

\section{MATERIAL BODIES AT WORK}

All of the articles, in line with our Call for Papers, take material, flesh-and-blood bodies, rather than the textual or discursively constructed body, as their point of departure. The overall research question that the authors explore is 'How and why do physical bodies matter?' The authors ask how far organizations take physical bodies into account in how they regulate workers and their clients; they give special importance to how workers use their bodies in work practices. However, for the authors in this Special Issue, the bodies of workers and clients are never merely physical; they are composed of social, psychological and biological elements, that together make up embodied attributes, characteristics and practices. Even flesh-and-blood bodies, as we have learned from Bourdieu, incorporate the social, through habit or habitus, in their shape, in their health, and in their relations with others. Material bodies incorporate biological processes but also intellectual and 
social capacities, including accent, deportment and taste. However, most of the authors of this Special Issue take this further; as Ahmed (cited by Grabham, 2008, p. 198) says, 'emotions get stuck to bodies' and sensations and emotions shape the movement of our bodies towards and away from objects and each other. Cohen and Wolkowitz also foreground the materiality of human bodies, seeing human bodies as a particularly intractable material of production. Writing in the tradition of labour process analysis, Cohen and Wolkowitz demonstrate why working on and with human bodies presents particular 'body work dilemmas', which employers must resolve through strategies for recruiting and deploying labour. Bodies are varied, unpredictable, and indivisible, and, therefore, workers do not only need to be present when their clients or customers need attention but must also meet unpredictable peaks in demand for labour. Body work enterprises such as care work agencies and hairdressing salons, the examples the authors take as exemplars, are only commercially viable if they can access a low-paid labour force (e.g. women, migrants, ethnic minorities) willing to respond to customers' and clients' sudden needs.

Swan and Flowers suggest, however, that the centrality of the materiality of bodies and of bodily interactions is not confined to interactions involving physical touch. What we learn from Swan and Flowers's account of the body work undertaken by tour guides in Sydney is that even tour guides face what Cohen and Wolkowitz call 'body work dilemmas', in this case as individuals presented with difficult clients. In particular, guides need to manage the bodily reactions of tour participants, whose 'noses wrinkle, mouths grimace, faces turn away, and tongues protrude' when faced with foods they see as racially other. The guides also have to learn how to manage their own responses. Additionally, the guides must use their own bodies to establish control of troublesome, racially charged interactions and to maintain their authority. The authors identify 'smiling', 'vocalization' and 'shepherding' as key ways for guides to work with their own bodies to manage encounters with tourists. Smiling is a way of accommodating rude tourists, encouraging 
tour participants to try different foods, and hiding the guides' own feelings. Vocalization refers to the ways that guides deliberately vary the tone and volume of their voices to maintain the participants' focus and enthusiasm. Lastly, shepherding refers to gestures and bodily movements through which guides set the pace and monitor the tourists. To do this, they vary their walking speed, turn around, or, when necessary, walk back- wards to see if everyone is keeping up. Therefore, the physical body is invoked and deliberately managed in order to achieve both employer's organizational goals (satisfied participants) and guides' own dignity as members of the communities the tours visit.

Rajan-Rankin's study of the interactions of Indian call centres takes this discussion even further. She shows that physically embodiment is central for how call centre workers, managers and distant American clients interact electronically. Ranjan-Rankin sees 'the body' as workers' main locus of identity and emotional management in the organizations she studied. This is ironic as we are accustomed to thinking of voice-based electronic communication as disembodied, and indeed some call centre workers describe dealing with their 'absent-present' body as a problem. However, the Rajan- Rankin analysis shows that, far from being disembodied, the workers' fleshy bodies (and the symbolic representation of them) are key issues; thus, 'bodies matter in call centre work', as she states. First, managers target workers through what she calls body-regulation practices, including through training and surveillance; for instance, how they sit, or what personality and accent they adopt. Second, workers do body work on their own bodies, both to meet managers' expectations and to defend their sense of self. Lastly, workers interact with (and manage abuse by) customers by developing 'corporeal imaginaries' through which they visualize and 'enflesh' western telephone callers.

Two other articles in this Special Issue highlight how variable physical interactions are, and consider in particular the ideologies and interests that structure this variability. Hansen and 
Kamp's study of Danish domiciliary care for the elderly show how the interactions between clients (or citizens, in Danish parlance) and care workers and occupational and physical therapists have been reorganized due to a new ideology of rehabilitative care that prioritizes training citizen-clients in doing things for themselves over help from care workers. This presents care workers with new 'body work dilemmas' over how they interact with clients, and how they regard their own bodies.

Like the articles by Lee and by Yates, Riach and Johansson suggest, relations between flesh-and-blood bodies are also shaped by broader discourses, including especially organizational discourses. Lee points to broadly couched, dualistic constructions of bodies that have important consequences for how breastfeeding practices are changing. Lee highlights the incompatible normative constructions of appropriate workplace bodies in contrast to the practice of breastfeeding as a necessary feature of intensive mothering. Lee suggests that the rise of a medicalized and mechanistic view of breast milk as a product has become popular partly because this view can be accommodated within our understanding of productive work, while the intimate, embodied relation in which breastfeeding traditionally occurs cannot. Breastfeeding involves a relation of what Diprose (2002) termed 'corporeal generosity', or corporeal openness, which is not easily accommodated by most workplaces. The relation between mother and baby shapes how breast milk is produced; mother and baby are interdependent. Not only does the baby require milk, the breastfeeding mother depends on the baby's sucking to produce it. Drawing on Diprose's initial work, the authors argue that when lactating mothers are forced to express and store breast milk, instead of feeding their babies directly, this subordinates their physical and emotional relation to their babies to the dictates of the contemporary organization. Moreover, the biological basis of breastfeeding (along with other kinds of reproductive labour) means it is not even viewed as a form of work. In this article Lee's argument anticipates other attempts to understand in vivo activities, 
such as participation as drug test subjects, surrogacy and tissue and organ 'donation' as 'biolabour' (Cooper and Waldby, 2014; see also Clarke et al., 2010).

Finally, it is important to stress that not only do bodily interactions vary, our consciousness of our individual physical embodiment changes from time to time. Yates, Riach and Johansson's article on experiences of stress recounted by women senior police officers in the UK thus deploys Leder's (1990) phenomenological account of the 'absent body'. The absent body suggests that our bodies recede from consciousness only for us to be taken aback when they 'dysappear' through pain or discomfort. Yates, Riach and Johansson, like our other authors, thus recognise that experiences of the dys-appearance of our bodies into consciousness are always situated within powerful and complex (organizational) knowledge systems that deny some perceptions and privilege others.

\section{GENDERED BODIES}

How far gender enters into our authors' perceptions of the physical body and their research participants' bodily experiences varies. Rather oddly, we did not mention gender in our original Call for Papers, perhaps imagining that the journal title, Gender, Work and Organization, spoke for itself. Yet, gender is indeed part of the analysis in most articles, although not always as explicitly as one could wish. Gender is sometimes constructed as only an additional variable that runs alongside the bodily experiences women and men share. However, as several of the other authors insist, along with the other forms of 'Othering' gender constructions and gendered identities are integral to our experience of embodiment, of being bodied.

Yates and her co-authors go furthest in this direction. In their ambitious attempt to gender Leder's (1990) understanding of the 'absent body' that characteristically recedes from consciousness, they draw on Oakley's (2007) Fracture, which argues that maintaining a sense of 
bodily integrity is particularly taxing for women. Building also on Young's (2005) phenomenological account of engaging the world from a sexed body, Yates and her co-authors show the existence of 'gendered lines of recognition' in our perception of stress. There are 'organizationally sanctioned' ways of articulating stress in a police context, which means that it is the legitimacy of women's stress that is especially challenged; consequently, the recognition of it is inhibited. The authors suggest that for the women police officers to acknowledge stress, they had to battle professional and occupational expectations of a limitless body that not only survives but actually thrives on exertion and endurance.

Cohen and Wolkowitz see gender as a lens through which occupations involving physical interactions between bodies are generally understood. Implicitly rejecting the adequacy of a macro view of the gendering of service sector work overall, they follow Ashcraft (2013) in problematizing the 'symbolic alignment' between particular jobs and the 'emblematic bodies' that come to symbolise them. Like Ashcraft, they analytically separate job and gender in order to see how they have been brought together, historically, in particular occupations (and how the gendering of particular occupations may change). Cohen and Wolkowitz propose that wider cultural assumptions about who can touch whom, and what that touch means, have been central to why most kinds of paid body work are linked to women. Women's bodies identify certain kinds of body work with caring feelings for others (and by the same token render somewhat invisible the control of others which the same jobs may entail).

Hansen and Kamp's article illustrates the historical contingency of links between gender and job particularly well. These researchers argue that domiciliary assistants are now expected not to touch clients, with workers being told to keep their hands behind their backs to ensure that they remember not to reach out to help. Helping behaviour is now condemned and is associated with female 'caring genes' (see also Jensen, forthcoming) that even women workers 
should strive to subdue. This defeminization of the care-worker role is accompanied by the professionalization of the workers' bodies, and the privileging of analytical and goal-oriented skills, associated with masculinity, over relational work. In this article, we see how some body work dilemmas (in this case, what to do with one's body) are not just located within wider ideological and material contexts, but even created by them.

The other authors of the Special Issue vary in how much explicit attention they give to gender, even though we can see that gender is greatly a part of their story. For instance, Lee's account of breastfeeding uses the term gender only rarely, although the whole tenor of her discussion locates (lactating) women's bodies as Other to organization, and Other to the men's bodies on which organizational bodies are modelled. In Lee's article, gender is central to the analysis, even if implicitly discussed, whereas other authors grasp the gendered body work in a more incidental manner. For instance, Rajan-Rankin notes that some of her participants in the call centre deployed their bodies in specifically gendered ways to assert their bodily being, but does not examine this systematically. Likewise, Swann and Flowers recognize that all the food tour guides were women, and brings gender into author's understanding of why these women guides faced particularly difficulties in asserting their authority; but the authors do not highlight gender identities in their analysis of all the body work dilemmas the guides face. The relative absence of gender analysis in these latter two articles is convincing because, according to their authors, the workplace encounters are constructed by both workers and clients mainly in terms of racialized fantasies and stereotypes. These authors see the intensity of feeling evoked by 'inequalities and the histories of inequalities' (Grabham, 2008, p. 198) as the most important influence on workers' embodied interactions with clients. 


\section{WHERE DO WE GO FROM HERE?}

Looking back over the articles, it is clear that making bodies visible (and tangible) within and in relation to organizations is an important endeavour, although it may not be easy. This difficulty is especially true in regard to employment and organizational studies that attempt to go beyond the usual focus on body image or surface inscription. As Hansen and Kamp's analysis shows, in Denmark bodily impairment is recognized by the very substantial physical care that has been available for elderly citizens, only to be denied or marginalized by recent rehabilitative care policies that restrict it. Several of the articles in this Special Issue are inspired by the concept of 'body work', and this concept has provided a way for scholars to recognize the extent to which bodies interact in the workplace - whether co-present or not - and whether or not physical touch is involved. How bodies are used may follow the explicit instructions of management (do not touch, use this ac-cent and not another), implicit directives or norms (refuse to recognize one is stressed, do your breastfeeding somewhere else), or to exercise some sense of agency (through presentations of self, for instance). Organizational norms often have to do with the denial of workers' (and/or clients') bodily vulnerability and with the exclusion of reproductive activities from the centre of an organization. It may be that the notion of 'body work dilemmas' - the quandaries workers and employers face when deciding how to organize body work, how to manipulate clients' bodies, and how to use their own bodies - could be a fruitful concept to use if we want to investigate further the problems associated with bodily interactions in organizations and how much agency workers en-joy in their relations with others and the ways they manage their own bodies.

\section{REFERENCES}

Ahmed, S. and Stacey, J. (2001) Thinking through the Skin. London and New York: Routledge. 
Ashcraft, K.L. (2013) The Glass Slipper: 'Incorporating' Occupational Identity in Management Studies. Academy of Management Review, 38,1, 6-31.

Clarke, A.E., Mamo, J., Fosket, J.R., Fishman, J. and Shim, J.K. (2010) Biomedicalization: Technoscience, Health, and Illness in the US. Durham, NC: Duke University Press. Cooper, M. and Waldby, C. (2014) Clinical Labor: Tissue Donors and Research Subjects in the Global Bioeconomy. Durham, NC: Duke University Press.

Cooper, R. (2009) The Generalized Social Body: Distance and Technology. Organization, 17,2, $242-56$.

Coupland, C. (2015) Organizing masculine bodies in rugby league football: groomed to fail. Organization, 22,6, 793-809.

Courpasson, D. and Monties, V. (2016) 'I Am My Body’: Physical Selves of Police Officers in a Changing Institution. Journal of Management Studies, 54,1, 32-57.

Diprose, R. (2002) Corporeal Generosity: On Giving with Nietzsche, Merleau-Ponty, and Levinas. New York, NY: SUNY Press.

Fotaki, M., Kenny, K. and Vachhani, S. (2017) Thinking critically about affect in organization studies: Why it matters. Organization, 24,1, 3-17.

Grabham, E. (2008) 'Intersectionality: Traumatic Impressions’. In Grabham, E., Cooper, D., Krishnadas, J. and Herman, D. (eds) Intersectionality and Beyond: Law, Power and the Politics of Location. Abingdon: Routledge-Cavendish, pp. 183-202.

Gimlin, D. (2007) What is Body Work? Sociology Compass, 1,1, 353-70.

Hassard, J., Holliday, R. and Willmott, H. (2000) Body and Organization. London: Sage Publications.

Jeanes, E., Knights, D. and Yancy Martin, P.Y. (2011) Handbook of Gender, Work and Organization. Chichester: Wiley. 
Jensen, M. Gender Stereotypes and the Reshaping of Stigma in Rehabilitative Eldercare. Gender, Work \& Organization, forthcoming.

Johansson, J., Hanken, J.T. and Valtonen, A. (2017) The body, identity and gender in managerial athleticism. Human Relations, 70,9, 1141-67.

Kang, M. (2003) The Managed Hand: The Commercialization of Bodies and Emotions in Korean Immigrant-owned Nail Salons. Gender \& Society, 17,6, 820-39.

Kang, M. (2010) The Managed Hand: Race, Gender and the Body in Beauty Service Work. Berkeley, CA: University of California Press.

Küpers, W. (2009) The Sense-Making of the Senses: Perspectives on embodied aesthesis and aesthetics. Organising Aesthesis: International Journal of Art and Aesthetics in Management and Organizational Life, 2,2, 33-53.

Leder, D. (1990) The Absent Body. Chicago, IL: University of Chicago Press.

Mascia-Lees, F.E. (2011) 'Introduction'. In Mascia-Lees, F.E. (ed.) A Companion to the Anthropology of the Body and Embodiment. Chichester: Wiley-Blackwell.

McDowell, L. (2009) Working Bodies: Interactive Service Employment and Workplace Identities. Chichester, UK: Wiley.

Mik-Meyer, N. (2015) Gender and disability: Feminising male employees with visible impairments in Danish work organisations. Gender, Work and Organization, 22,6, 579-95.

Mik-Meyer, N. (2016a) Othering, ableism and disability: A discursive analysis of co-workers' construction of colleagues with visible impairments. Human Relations, 69,6, 1341-63.

Mik-Meyer, N. (2016b) Disability and 'care': Managers, employees and colleagues with impairments negotiating the social order of disability. Work, Employment \& Society, 30,6, 984-94.

Mol, A. (2002) The Body Multiple. Durham, NC: Duke University Press. 
Oakley, A. (2007) Fracture: Adventures of a Broken Body. Bristol: The Policy Press.

Pullen, A. and Rhodes, C. (2015) Ethics, embodiment and organizations. Organization, 22,2, 78296.

Purcell, C., Cameron, S., Lawton, J., Glasier, A. and Harden, J. (2017) The Changing Body Work of Abortion: A Qualitative Study of the Experiences of Health Professionals. Sociology of Health and Illness, 39, 1, 78-94.

Seigworth, G. and Gregg, M. (2010) An Inventory of Shimmers. In Gregg, M., Seigworth, G.J. (eds) The Affect Theory Reader. London: Duke University Press, pp. 1-28.

Shaw, R. (2014) Live Kidney Donation as Body Work. Critical Social Policy, 34,4, 495-514.

Shilling, C. (2003/1993) The Body and Social Theory. (2nd ed.) London: Sage.

Sims, R. (2009) Food, place and authenticity: local food and the sustainable tourism experience. Journal of Sustainable Tourism, 17,3, 321-36.

Twigg, J. (2000) Care Work as a Form of Bodywork. Ageing \& Society, 20, 389-411.

Twigg, J. (2006) The Body in Health and Social Care. Basingstoke: Palgrave.

Van den Brock, D. (2017) Perforated Body Work: The Case of Tele-nursing. Work, Employment \& Society available at: https://doi.org/10.1177/0891243203257632. (Last accessed 1 January 2017).

Williams, C. and Connell, C. (2010) Looking Good and Sounding Right. Work \& Occupations, $37,3,349-77$.

Wolkowitz, C. (2002) The Social Relations of Body Work. Work, Employment \& Society, 16,3, 497-510.

Wolkowitz, C. (2006) Bodies at Work. London: Sage Publications.

Young, I.M. (2005) On Female Body Experience. Oxford: Oxford University Press. 